\title{
Exercise and Heat Stress in Cystic Fibrosis Patients
}

\author{
DAVID M. ORENSTEIN, ${ }^{(21)}$ KATHE G. HENKE, DAVID L. COSTILL, ${ }^{(19)}$ CARL F. DOERSHUK, \\ PETER J. LEMON, ${ }^{(20)}$ AND ROBERT C. STERN \\ Department of Pediatrics, University of Tennessee Center for the Health Sciences, Le Bonheur Children's Medical \\ Center, Memphis; Case Western Reserve University, Rainbow Babies and Childrens Hospital, Cleveland, Ohio, USA
}

\begin{abstract}
Summary
Cystic fibrosis (CF) is characterized by high sweat sodium and chloride concentrations. CF patients have long been assumed to be at risk for heat illness, but there has been no quantitative documentation that $\mathrm{CF}$ patients actually have a greater loss of sodium and chloride than normals when under environmental stress. We compared thermoregulatory responses of eight CF patients with five normal controls during 90-min exposures to exercise and heat stress. Both groups reached similar peak rectal temperatures and peak heart rates; they had similar sweat volumes and rates. CF patients showed the normal rise in renin and aldosterone and the normal fall in urine sodium excretion; however, CF patients lost significantly more sodium $(\mathbf{4 8 . 8} \pm \mathbf{2 3 . 4} \mathrm{mEq} / \mathrm{liter} /$ $\mathrm{m}^{2}$ versus $\left.20.2 \pm 11.2 \mathrm{mEq} / \mathrm{liter} / \mathrm{m}^{2}\right)$ and chloride $(46.6 \pm 21.6$ $\mathrm{mEq} / \mathrm{liter} / \mathrm{m}^{2}$ versus $18.5 \pm 11.3 \mathrm{mEq} / \mathrm{liter} / \mathrm{m}^{2}$ ) per unit of surface area than the controls. Serum sodium and chloride concentrations fell in the CF patients but not in the normals. After exercise/heat stress, CF serum chloride was significantly less than normals' (99 $\pm 3 \mathrm{mEq} /$ liter versus $104 \pm 1 \mathrm{mEq} /$ liter, $P<0.01$ ).

CF patients have normal temperature, heart rate, hormonal, and renal responses to exercise and heat stress, yet still lose significantly more sodium and chloride than normal. These losses are reflected in part in lower serum concentrations of these ions. There may be important effects of these losses on respiratory tract secretions.
\end{abstract}

\section{Abbreviations}

CF, cystic fibrosis

NS, not significant

Cystic fibrosis (CF) is characterized by high sweat sodium and chloride concentrations (17), and CF patients are assumed to be at risk for sustaining excessive loss of these ions with exercise or exposure to high environmental temperatures. The sweat abnormality was discovered in 1953 when di Sant' Agnese et al. (5) followed up on the observation that a disproportionate number of children hospitalized during a heat wave with heat illness had cystic fibrosis (5). Furthermore, CF patients may have decreased serum electrolyte concentrations as the first recognizable manifestation of their disease $(2,11)$. Several investigators have discussed possible sequences of events which occur with salt depletion in CF $(6,12)$. But experimental documentation that $\mathrm{CF}$ patients actually lose large amounts of salt in their sweat and are thus really at risk for developing heat illness has not been published. We measured thermoregulatory and hormonal responses of CF patients with mild lung disease but typical sweat abnormality during 90 -min exposures to exercise in the heat and compared them to normal persons. Our findings provide the experimental data to support the observation of CF patients' susceptibility to heat illness.

\section{METHODS AND SUBJECTS}

Eight CF patients, four male and four female, age 12-31 years volunteered for study. Five normal volunteers, two male and three female, age 16-35 years, with no history, signs, or symptoms of lung disease, served as controls. Informed consent was obtained. $\mathrm{CF}$ was diagnosed by a positive sweat test (sweat chloride concentration greater than $60 \mathrm{mEq} /$ liter) and either typical pulmonary or digestive symptoms or a family history of the disease (17).

Progressive exercise tests were performed on an electronically braked Siemens-Elema cycle ergometer in our computerized laboratory (1), following Godfrey's protocol (7): subjects began with 1 min of unloaded pedaling, and had work increments of 20 watts added each successive minute until they could no longer pedal. Peak oxygen consumption $\left(\mathrm{VO}_{2}\right)$ and peak heart rate were recorded. The combined exercise and heat stress portion of the study was carried out on another day in an environmental chamber at an ambient temperature of $37-38^{\circ} \mathrm{C}$ dry bulb, and $24-29^{\circ} \mathrm{C}$ wet bulb. After a 10-min accomodation period in the chamber, subjects pedaled on cycle ergometers for $70 \mathrm{~min}$ at $50 \%$ of their peak $\mathrm{VO}_{2}$, and then recovered for another $10 \mathrm{~min}$. Rectal temperatures (by Yellow Springs Instruments temperature probe) and ECG were monitored. Subjects had continuous free access to water. Sweat was collected by total body washdown (14) for determination of sweat electrolyte losses. Body weight was measured before and after the exercise/heat stress; respiratory water loss was estimated (13); and sweat volume calculated. Before and after the heat stress, urine and serum osmolality and sodium and potassium concentrations and serum renin activity and chloride and aldosterone concentrations were determined by standard methods. Student's $t$ test was used to compare group results, and the paired $t$ test was used to evaluate changes before and after the exercise/heat stress.

\section{RESULTS}

Patient characteristics are presented in Table 1. Seven of the eight CF patients and four of the five control subjects completed the exercise and heat stress tests. We interrupted the exercise in one 15-year-old male CF subject and one 16-year-old male control subject when they complained of dizziness and nausea and their rectal temperatures reached $39.1^{\circ} \mathrm{C}$ and $39.2^{\circ} \mathrm{C}$, respectively, with heart rates of $184 \mathrm{bpm}$ and $194 \mathrm{bpm}$, after 40 and $45 \mathrm{~min}$ of pedaling. Both were able to complete $90 \mathrm{~min}$ in the heat without further difficulty once they stopped pedaling.

Peak $\mathrm{VO}_{2}(38.1 \pm 15.3 \mathrm{ml} / \mathrm{kg} / \mathrm{min}$; mean \pm S.D. $)$ for the $\mathrm{CF}$ patients was not significantly different from controls $(36.4 \pm 10.1$ $\mathrm{ml} / \mathrm{kg} / \mathrm{min}$ ). There were also no significant differences with respect to baseline urine electrolytes or serum electrolytes, renin, or aldosterone.

Responses to exercise and heat stress are summarized in Table 2 and Figures 1-3. Both groups reached similar peak rectal temperatures and peak heart rates. Both groups drank similar 
amounts of water. Both had similar sweat volumes; however, the CF patients had significantly higher concentrations of sodium and chloride in their sweat. They lost significantly more sodium and chloride per unit of surface area than did the controls. Serum

Table 1. Patient characteristics. Values given are group means and (S.D.) All differences statistically nonsignificant $(P>0.05)$.

\begin{tabular}{lcc}
\hline & $\begin{array}{c}\text { Cystic fibrosis } \\
(n=8)\end{array}$ & $\begin{array}{c}\text { Control } \\
(n=5)\end{array}$ \\
\hline Age $(\mathrm{yr})$ & 20 & 25 \\
& $(6)$ & $(9)$ \\
Height $(\mathrm{cm})$ & 164.6 & 162.8 \\
& $(9.5)$ & $(10.5)$ \\
Peak $\mathrm{VO}_{2}(\mathrm{ml} / \mathrm{kg} / \mathrm{min})$ & 38.1 & 36.4 \\
& $(15.3)$ & $(10.1)$ \\
\hline
\end{tabular}

Table 2. Cystic fibrosis $(C F)$ and control group responses to exercise and heat stress. Values given are group means and (S.D.).

\begin{tabular}{|c|c|c|}
\hline & $\begin{array}{c}C F \\
(n=8)\end{array}$ & $\begin{array}{l}\text { Control } \\
(n=5)\end{array}$ \\
\hline $\begin{array}{c}\text { Peak } \mathrm{T}_{\mathrm{re}} \\
\left(0^{\circ} \mathrm{C}\right)\end{array}$ & $\begin{array}{l}38.3 \\
(0.4)\end{array}$ & $\begin{array}{l}38.4 \\
(0.6)\end{array}$ \\
\hline $\begin{array}{l}\text { Peat heart rate } \\
\quad(\mathrm{bpm})\end{array}$ & $\begin{array}{l}161 \\
(16)\end{array}$ & $\begin{array}{l}167 \\
(21)\end{array}$ \\
\hline $\begin{array}{l}\mathrm{H}_{2} \mathrm{O} \text { consumed } \\
\quad(\mathrm{ml})\end{array}$ & $\begin{array}{l}746 \\
\quad(360)\end{array}$ & $\begin{array}{l}542 \\
\quad(267)\end{array}$ \\
\hline $\begin{array}{l}\text { Sweat volume } \\
\text { (ml) }\end{array}$ & $\begin{array}{l}958 \\
\quad(366)\end{array}$ & $\begin{array}{l}720 \\
(406)\end{array}$ \\
\hline $\begin{array}{l}\text { Sweat rate } \\
\qquad\left(\mathrm{ml} / \mathrm{m}^{2} / \mathrm{min}\right)\end{array}$ & $\begin{array}{c}7.36 \\
(2.13)\end{array}$ & $\begin{array}{c}5.57 \\
(2.17)\end{array}$ \\
\hline $\begin{array}{l}\text { Sweat } \mathrm{Na}^{+} \text {conc. } \\
(\mathrm{mEq} / \text { liter })\end{array}$ & $\begin{array}{r}76^{1} \\
(23)\end{array}$ & $\begin{array}{l}43 \\
(9)\end{array}$ \\
\hline $\begin{array}{l}\text { Sweat } \mathrm{Cl}^{-} \text {conc. } \\
(\mathrm{mEq} / \text { liter })\end{array}$ & $\begin{array}{r}73^{1} \\
(20)\end{array}$ & $\begin{array}{l}39 \\
(10)\end{array}$ \\
\hline $\begin{array}{c}\text { Sweat } \mathrm{K}^{+} \text {conc. } \\
(\mathrm{mEq} / \text { liter })\end{array}$ & $\begin{array}{c}6.4 \\
(3.6)\end{array}$ & $\begin{array}{c}6.8 \\
(1.8)\end{array}$ \\
\hline $\begin{array}{l}\text { Sweat } \mathrm{Na}^{+} \text {lost } \\
\left(\mathrm{mEq} / \mathrm{m}^{2}\right)\end{array}$ & $\begin{array}{r}48.81^{1} \\
(23.44)\end{array}$ & $\begin{array}{c}20.22 \\
(11.15)\end{array}$ \\
\hline $\begin{array}{l}\text { Sweat } \mathrm{Cl}^{-} \text {lost } \\
\left(\mathrm{mEq} / \mathrm{m}^{2}\right)\end{array}$ & $\begin{array}{r}46.61^{1} \\
(21.58)\end{array}$ & $\begin{array}{c}18.48 \\
(11.31)\end{array}$ \\
\hline $\begin{array}{l}\text { Sweat } \mathrm{K}^{+} \text {lost } \\
\left(\mathrm{mEq} / \mathrm{m}^{2}\right)\end{array}$ & $\begin{array}{c}3.78 \\
(2.43)\end{array}$ & $\begin{array}{c}2.74 \\
(0.91)\end{array}$ \\
\hline
\end{tabular}

${ }^{1} \mathrm{CF}$ significantly different from control $(P<0.05)$. chloride concentrations fell signiticantly $(P<0.05)$, serum sodium concentrations fell (NS), and potassium concentrations rose (NS) for the CF patients after the heat and exercise exposure (Table 3 , Fig. 1). CF serum osmolality also decreased significantly $(P<$ 0.02 ). The control subjects' serum sodium and chloride concentrations and osmolality remained unchanged, whereas their serum potassium concentration rose (NS). The difference between the $\mathrm{CF}$ and control serum chloride concentrations after the heat/ exercise stress was significant $(P<0.01)$. Both $\mathrm{CF}$ and control subjects responded to heat and exercise stress with significantly decreased urinary sodium $(P<0.05)$ and slightly increased urinary potassium concentration (Table 3, Fig. 2). The two CF patients whose urinary potassium fell were those who drank free water in excess of their weight loss. Both groups of subjects increased both their plasma renin activity and serum aldosterone concentration with heat and exercise stress (Fig. 3). All of these changes except the control renin were statistically significant.

\section{DISCUSSION}

In this study we found eight $\mathrm{CF}$ patients with mild lung disease to have normal exercise and heat tolerance. Their heart rates and

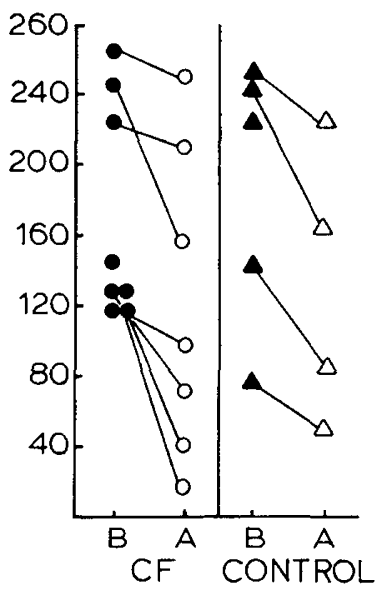

URINE $\mathrm{Na}^{+}(\mathrm{mEq} / \mathrm{L})$

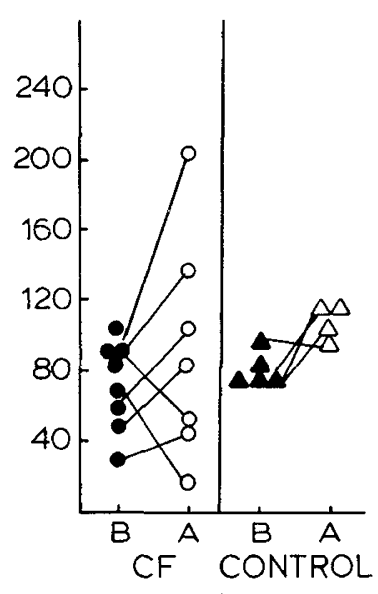

URINE $\mathrm{K}^{+}(\mathrm{mEq} / \mathrm{L})$
Fig. 2. Urine electrolyte concentrations in $\mathrm{CF}$ and control groups before and after exercise and heat stress. Symbols the same as Figure 1. Both groups had significantly decreased urine sodium concentration after exercise and heat $(P<0.05)$.
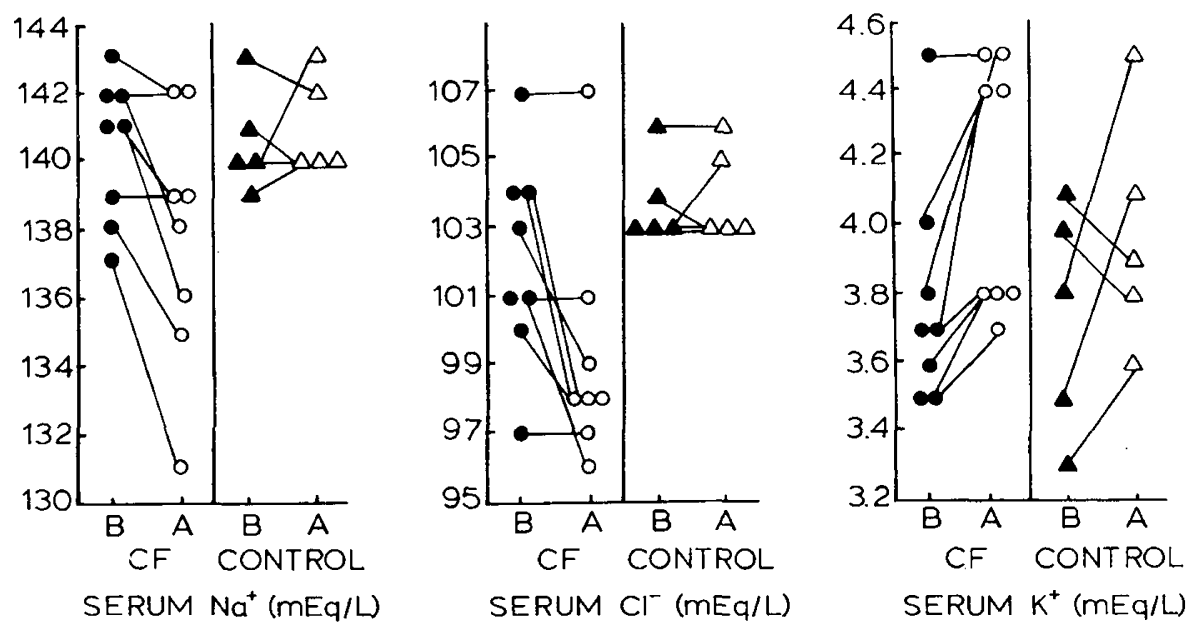

Fig. I. Serum electrolyte concentrations in CF (circles) and control groups (triangles), before (solid symbols) and after (open symbols) exercise and heat stress. The CF serum chloride after stress is significantly different from CF before (by paired $t$ test, $P<0.05$ ), and from control serum chloride after stress $(P<0.01)$. 


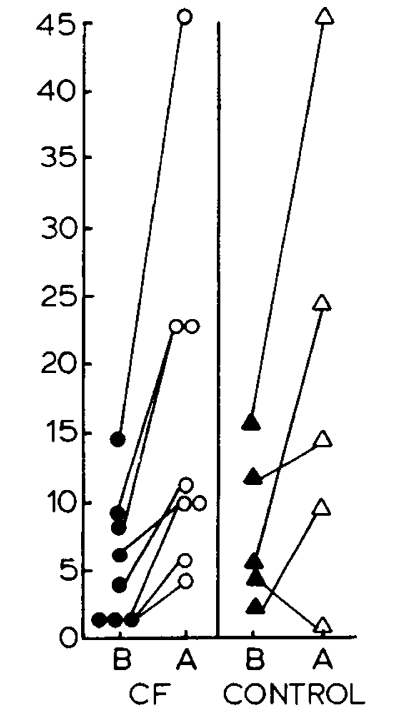

PLASMA RENIN ACTIVITY (ng/ml/hr)

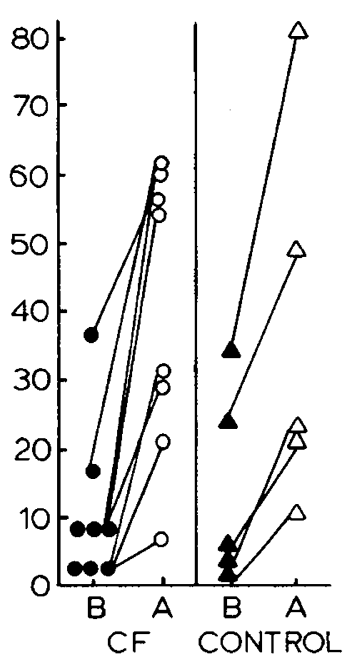

SERUM ALDOSTERONE (ng/dl)

Fig. 3. Plasma renin activity and serum aldosterone in $\mathrm{CF}$ and control groups before and after exercise and heat stress. Symbols the same as Figure 1. Both CF $(P<0.01)$ and control $(P<0.05)$ groups increased aldosterone concentrations significantly, and $\mathrm{CF}$ increased renin significantly $(P<0.05)$

rectal temperatures were the same as their non-CF peers in this 90-min bout of heat exposure, which included $70 \mathrm{~min}$ of exercise at $50 \%$ peak $\mathrm{VO}_{2}$. The $\mathrm{CF}$ patients achieved normal thermal and cardiac responses in part by having normal sweat volumes. Both the control and $C F$ sweat rates and volumes were comparable to published results for untrained, unacclimatized normal subjects $(3,18)$. Renin and aldosterone increases in response to the salt and fluid loss were similar in the two groups, and also comparable to published normal responses $(4,15)$. Although our urines were spot samples after free access to water, the results indicate that both groups had normal renal salt conservation, with lower urine sodium concentrations after exercise in the heat $(4,8,15)$. The small rise in serum potassium in both groups is also normal (3).

CF sweat contained significantly more sodium and chloride than that of the controls, and CF patients lost significantly more of both ions per $\mathrm{m}^{2}$ of body surface area than the controls did. These losses led to significantly lower serum chloride concentrations and serum osmolality and slightly lower serum sodium concentrations for the $\mathrm{CF}$ patients after the exercise and heat exposure.

This study has provided the experimental data to explain the observations of the apparent increased susceptibility to heat illness in CF. Although our relatively healthy $C F$ patients had normal thermal, renal, and cardiac responses to a single session of exercise in the heat, they did experience significant salt losses. It remains to be determined how CF patients respond to repeated exposures to exercise in the heat.

In addition to the potential for systemic heat illness which these salt losses represent, there may also be important implications related to CF lung disease. Knowles and colleagues (9) have reported significant differences between bioelectric potentials across respiratory epithelia of CF and non-CF subjects, apparently related to the CF epithelium's actively pumping sodium out of the lumen. The active loss of sodium, and the passive loss of water, from respiratory secretions would seem to explain the low water content of CF sputum (17), and help explain its apparently abnormal viscosity. If low total body sodium and the attendant high aldosterone increases the respiratory scavenging for sodium,

Table 3. Changes with exercise and heat stress. All values expressed as mean and (S.D.) CF, cystic fibrosis

\begin{tabular}{cccccc}
\hline & $\begin{array}{c}\text { Serum } \\
\mathrm{Na}^{+} \\
\text {conc. }\end{array}$ & $\begin{array}{c}\text { Serum } \\
\mathrm{Cl}^{-} \\
\text {conc. }\end{array}$ & $\begin{array}{c}\text { Serum } \\
\mathrm{K}^{+} \\
\text {conc. }\end{array}$ & $\begin{array}{c}\text { Urine } \\
\mathrm{Na}^{+} \\
\text {conc. }\end{array}$ & $\begin{array}{c}\text { Urine } \\
\mathrm{K}^{+} \\
\text {conc. }\end{array}$ \\
\hline CF-pre & 140 & $102^{1}$ & 3.8 & $171^{1}$ & 71 \\
$(n=8)$ & $(2)$ & $(3)$ & $(.3)$ & $(63)$ & $(24)$ \\
CF-post & 138 & $99^{1,2}$ & 4.1 & $120^{1}$ & 92 \\
$(n=8)$ & $(4)$ & $(3)$ & $(.4)$ & $(88)$ & $(64)$ \\
Control-pre & 141 & 104 & 3.7 & $188^{3}$ & 81 \\
$(n=5)$ & $(2)$ & $(1)$ & $(.3)$ & $(76)$ & $(8)$ \\
Control-post & 141 & $104^{2}$ & 4.0 & $133^{3}$ & 108 \\
$(n=5)$ & $(1)$ & $(1)$ & $(.3)$ & $(79)$ & $(11)$ \\
\hline
\end{tabular}

${ }^{\prime} \mathrm{CF}$ after is a significant decrease from $\mathrm{CF}$ before (paired $t$ analysis).

${ }^{2} \mathrm{CF}$ after significantly different from control after.

${ }^{3}$ Control after significantly different from control before (paired $t$ analysis).

as is the case in isolated baboon and human (both CF and non$\mathrm{CF})$ respiratory epithelia $(10,16)$, then exercise in the heat may put $\mathrm{CF}$ patients at risk for further dehydration of respiratory secretions and increased pulmonary embarrassment.

\section{REFERENCES AND NOTES}

1. Bacevice, A. E., Hellerstein, H. K., and Katona, P. G.: An automated system for estimating cardiac output by a rebreathing technique. Proceedings 29th Annual Conference on Engineering in Medicine and Biology. Boston, 1976.

2. Beckerman, R. C., and Taussig, L. M.: Hypoelectrolytemia and metabolic alkalosis in infants with cystic fibrosis. Pediatrics, 63: 580 (1979).

3. Costill, D. L.: Sweating: its composition and effects on body fluids. Ann NY Acad Sci., 301 : 160 (1977).

4. Costill, D. L., Branam, G., Fink, W., and Nelson, R.: Exercise induced sodium conservation: changes in plasma renin and aldosterone. Med. Sci. Sports, 8: 209 (1976).

5. di Sant' Agnese, P. A., Darling, R. C., Perera, G. A., and Shea, E.: Abnormal electrolyte composition of sweat in cystic fibrosis of pancreas. Pediatrics, 12 . 549 (1953).

6. di Sant' Agnese, P. A., and Powell, G. F. The eccrine sweat defect in cystic fibrosis of the pancreas (mucoviscidosis). Annals N. Y. Acad. Sci., 93: 555 (1962).

7. Godfrey, S. Exercise testing in children. p. 30. (WB Saunders, London, 1974).

8. Kachadorian, W. A., and Johnson, R. E.: Renal responses to various rates of exercise. J. Appl. Physiol., 28: 748 (1970).

9. Knowles, M., Gatzy, J., and Boucher, R.: Increased bioelectric potential difference across respiratory epithelia in cystic fibrosis. New Engl. J. Med., 305: 1489 (1980).

10. Legris, G., Will, P. C., and Hopfer, U.: Human and baboon bronchial sodium absorption: implications for airway fluid movement and mucociliary clearance mechanism. Chest, 81 (Suppl.): 9S-11S (1982).

11. Nussbaum, E., Boat, T. F., Wood, R. E., and Doershuk, C. F.: Cystic fibrosis with acute hypoelectrolytemia and metabolic alkalosis in infancy. Am. J. Dis. Child., 133: 965 (1979)

12. Simopoulos, A. P., Lapey, A., Boat, T. F., di Sant' Agnese, P. A., and Barter, F. C.: The renin-angiotensin-aldosterone system in patients with cystic fibrosis of the pancreas. Pediatr. Res., 5: 626 (1971).

13. Snellen, J. W.: Mean body temperature and the control of thermal sweating. Acta. Physiol. Plarmacol. Neerl., 14: 99 (1966).

14. Vellar, O. D.: Studies on sweat losses of nutrients. Scan. J. Clin. Lab. Invest., 21: 157 (1968).

15. Wade, C. and Claybaugh J.: Plasma renin activity, vasopressin concentration, and urinary excretory responses to exercise in man. J Appl Physiol: Respir. Environ. Exercise Physiol., 49: 930 (1980).

16. Will, P. C., Lebowitz, J. L., and Hopfer, U.: Induction of amiloride-sensitive sodium-transport in the rat colon by mineralocorticoids. Am. J. Physiol., 238: f261 (1980)

17. Wood, R. E., Boat, T. F., and Doershuk, C. F.: State of the art: cystic fibrosis. Am. Rev. Respir. Dis., 113: 833 (1976).

18. Wyndham, C. H.: Effect of acclimatization on the sweat rate/rectal temperature relationship. J. Appl. Physiol., 22: 27 (1967).

19. Ball State University, Muncie, Indiana.

20. Applied Physiology Research Laboratory, Kent State University, Kent, Ohio.

21. Requests for reprints should be addressed to: Dr. David Orenstein, Le Bonheur Children's Hospital, One Children's Plaza, Memphis, TN 38103.

22. Supported in part by NIH Grant AM 08305, HL 07415, The Cystic Fibrosis Foundation, and United Way Services of Cleveland.

23. Received for publication April 14, 1982.

24. Accepted for publication August 9, 1982 